Article

\title{
The "Four Core Elements" as a Measuring Instrument: From Simplicity to Complexity in Tourist Destination
}

\author{
Gema Pérez-Tapia $^{1, *(\mathbb{D})}$, Fernando Almeida-García ${ }^{2}$ (D) and Pere Mercadé-Melé $^{3}(\mathbb{D}$ \\ 1 Faculty of Commerce and Management, Campus of Teatinos, University of Malaga, 29071 Málaga, Spain \\ 2 Tourism Intelligence and Innovation Research Institute (i3t), Faculty of Tourism, Campus of Teatinos, \\ University of Malaga, 29071 Málaga, Spain; falmeida@uma.es \\ 3 Department of Statistics and Econometrics, Tourism Intelligence and Innovation Research Institute (i3t), \\ Faculty of Economic Science and Business, University of Malaga, 29071 Málaga, Spain; pmercade@uma.es \\ * Correspondence: gema.perez@uma.es
}

check for updates

Citation: Pérez-Tapia, Gema, Fernando Almeida-García, and Pere Mercadé-Melé. 2021. The "Four Core Elements" as a Measuring Instrument: From Simplicity to Complexity in Tourist Destination. Economies 9: 53. https://doi.org/10.3390/

economies 9020053

Academic Editor: Angeliki

N. Menegaki

Received: 27 February 2021

Accepted: 31 March 2021

Published: 7 April 2021

Publisher's Note: MDPI stays neutral with regard to jurisdictional claims in published maps and institutional affiliations.

Copyright: (c) 2021 by the authors. Licensee MDPI, Basel, Switzerland. This article is an open access article distributed under the terms and conditions of the Creative Commons Attribution (CC BY) license (https:// creativecommons.org/licenses/by/ $4.0 /)$.

\begin{abstract}
An adequate image of a tourist destination is a key instrument to attract tourists who will contribute to the development and economic growth of the place. The objective of this study is to analyze the formation and measure of the destination image. It contains a novel analysis which breaks down the heterogeneous aspects traditionally included in the cognitive dimension of the image into factors that provide more in-depth knowledge of it. A model is used in which the image is related to the corporate image of companies abroad. An exploratory factorial analysis and a structural equation model are used to test the hypotheses formulated. The sample consists of 409 questionnaires submitted to citizens of South Korea. A new scale is proposed, including four basic elements which are essential for any destination. They will serve as the basis for the diagnosis of the tourist competitiveness of the same, facilitating the action on them and their improvement. Additionally, this scale, known as the four core elements, enables the measurement of a destination image to be standardized.
\end{abstract}

Keywords: destination image; destination competitiveness; cognitive dimension; cognitive elements; Spain; South Korea

\section{Introduction}

A destination's success is not only dependent on the destination itself, but it is also subject to the success or failure of the destinations which it competes with (Dwyer and Kim 2003). One way to meet these challenges is to attract tourists from new markets. This means that destination managers must have detailed knowledge of the most highly rated attributes of the destination, and they must convey and market the destination coherently and successfully (O'Leary and Deegan 2005).

The destination image is a basic factor in this context, since it plays a key role in tourists' decision-making processes both before and after they have chosen their holiday destination. The image is also essential for attracting the attention of potential tourists and in promoting satisfaction and loyalty among those who have already visited a destination (Cohen et al. 2014; Del Bosque and Martín 2008; O’Leary and Deegan 2005; Park et al. 2019).

Given the importance of the image in the process of selecting a tourist destination, it is essential to understand which factors influence the creation of the initial image. According to Crompton et al. (1992) and Gupta et al. (2020), knowledge of all the factors that influence the creation of the image helps tourism promotion agencies to project the appropriate image to their target markets. This image is influenced by several factors, including the tourist's personality, their socioeconomic characteristics, their culture and the sources of information they consult. In addition to the already-existing factors, corporate image has recently become an influential factor in the image (Pérez-Tapia et al. 2019). 
Most authors consider the destination image to be a structure consisting of two dimensions: a cognitive dimension, which refers to the individual's rational knowledge, and another affective dimension, which refers to the emotions aroused by the destination (Baloglu and McCleary 1999; Beerli and Martin 2004). Some authors argue that the relationship between the image's cognitive and affective dimensions creates a third conative dimension, which Gartner (1994) defined as a component "analogous to behavior."

A structured technique is usually used when measuring the image, in which attributes are proposed for evaluation. As Schroeder (1996) argued, these attributes or characteristics of the destination are interrelated, which can justify the existence of several dimensions including all of them. Empirical evidence has shown that there are various dimensions underlying the destination image, which makes it a multidimensional concept (Ahmed 1996; Milman and Pizam 1995).

Taking the model for creating the destination image proposed by Baloglu and McCleary (1999) as its starting point, this study provides a more comprehensive and in-depth vision of the process involved in its formation and focuses above all on the heterogeneous elements involved in the cognitive component of the destination image. It also aims to measure the influence of the corporate image on the perception of the destination image. This latter aspect is based on the studies carried out by Pérez-Tapia et al. (2019) on a corporate image and a destination image.

The interest of this research lies in its new analysis of the cognitive image, in addition to the corporate destination image and its influence on the affective destination image through the cognitive dimension. This analysis breaks down the cognitive destination image into a number of factors that play a crucial role in forming the destination image. This research is also relevant and innovative since it provides a new scale for measuring the components of the cognitive image dimension, which is of particular interest for measuring the image of any tourist destination. This scale has the aim of identifying a series of basic or essential elements which a destination must have in order to be competitive.

Most previous studies have examined the affective and cognitive dimensions of the target image separately, as well as the influence of the cognitive dimension on the affective dimension. However, few scholars have considered the cognitive dimension of the image as a sum of factors or constructs, which arise from tourists' perceptions of the various attributes offered by the destination. The cognitive dimension of the image is measured using a number of the destination's characteristics or attributes in a process that provides a general evaluation of the place, but it does not promote in-depth knowledge of it because the attributes are very different from each other. It seems necessary to break down the cognitive image into factors that are homogeneous in themselves and heterogeneous in terms of each other to obtain a more in-depth understanding of this dimension.

The aim is to ascertain which dimensions underlie Spain's destination image among South Korean citizens, determine the influence that Spanish companies and their perceived corporate image may have, as well as identify which components of the cognitive image act as mediators in the relationship between the corporate image and the affective image. Moreover, we highlight the importance of various cognitive factors for understanding the relationship between the corporate and affective images. These items show us the traveler's perception of the destination in more detail (Figure 1). 


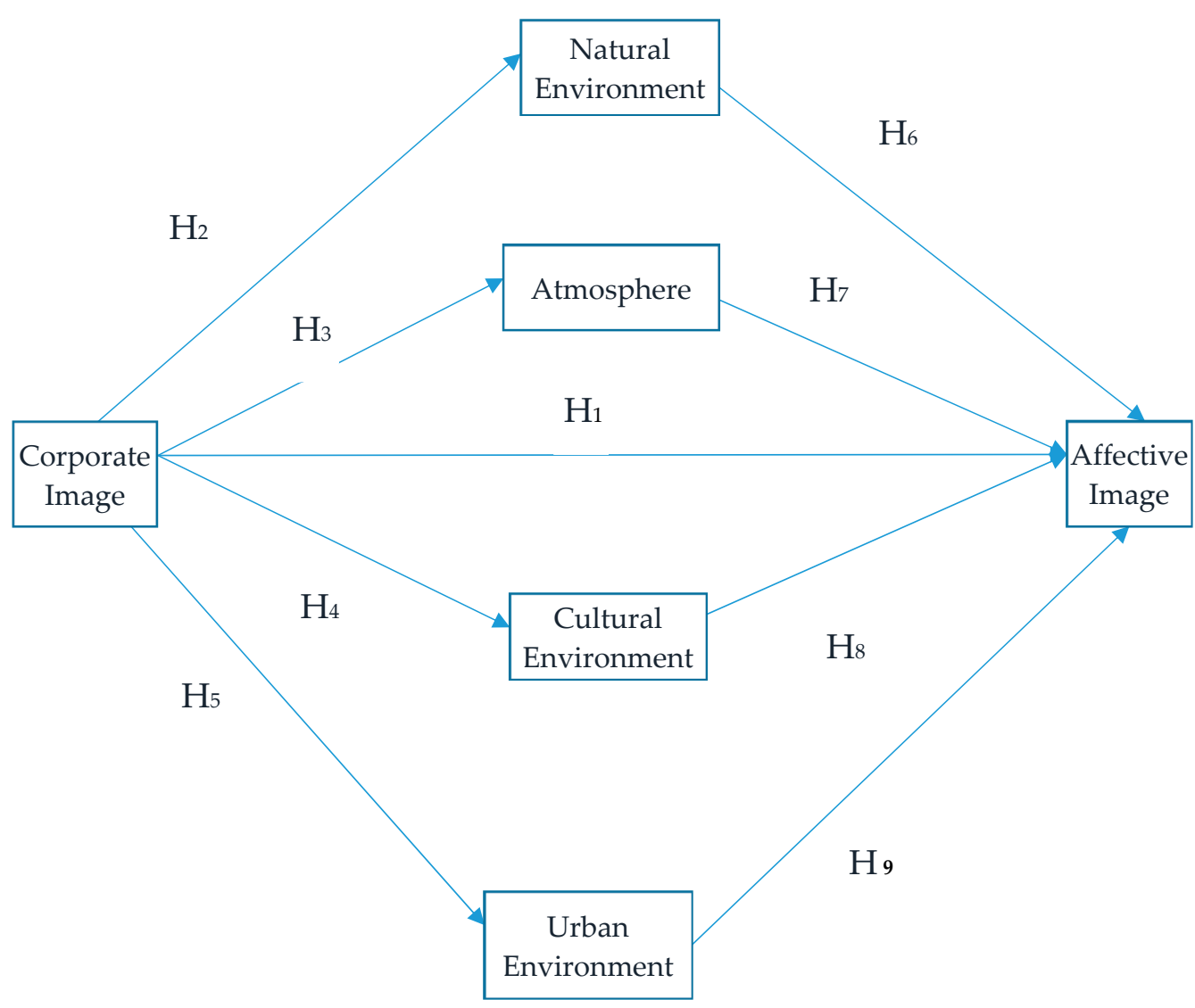

Figure 1. Proposed theoretical model.

\section{Literature Review}

The corporate image plays an increasingly important role in companies' strategic policies. The changes that have taken place in the market in recent decades have been increasing dramatically: new technologies, new businesses and new competitors. In order to address these changes successfully, companies must create a strategy which consists of reinforcing or modifying the way in which companies are perceived by consumers. They must clearly and effectively convey an image that reflects their purpose, objectives and strategies. This image must enable them to stand out, be recognized and operate in a competitive, demanding and dynamic market (Rodríguez et al. 2007).

The corporate image is a subjective assessment of the company in the mind of the consumer and is thus not part of the organization's structure (Brooks et al. 2009). Each target market will be interested in different aspects of the company's activity (Fombrun 2015).

Each of the company's target markets is exposed to many signals, but they do not retain all the information. This is a selective process in which each group selects the elements of the company that interest them most, and the group forms an overall image based on these (Rindova 1997). According to the main studies, a company has not just one image, but as many images as there are individuals interacting with it (Markwick and Fill 1997).

According to Capriotti (2009), the first step to obtain and properly assess a company's corporate image is to determine the variables or attributes which each target market uses to construct the corporate image. Importantly, each target market may have different valuation parameters, since their interests differ depending on their relationship with the organization. A group of consumers, suppliers or shareholders has a different perception of a company's corporate image.

Due to the lack of information about certain companies, individuals often tend to gather information from its environment and rely on this information when evaluating it 
(Highhouse et al. 2007). The image of any company's country of origin can be considered an important indication for its evaluation.

Regarding the relationship between the images (i.e., the corporate image and the country image), most research has established that there is a one-way relationship between the image of a given country and the image of its products (Papadopoulos et al. 1990), stating "the country as exporter, importer, and potential tourism, investment, or immigration destination, making its image a matter of vital importance to anyone living or otherwise interested in it" (Papadopoulos and Heslop 2003, p. 427).

Bernstein (1984) was one of the first authors to consider the country image in terms of a factor that can shape the corporate image. Other studies include those by Dowling (1993) and by Balmer and Gray (2003), which argue that the country's image influences the corporate image in one way or another.

The other side of the relationship (the influence that the corporate image may have on the country's image) has been the subject of fewer studies. Dowling (1993) and López et al. (2011) are among the few authors who have examined the reciprocal relationship between the corporate image and a country's image (the company's image that is affected by and affects the country's image).

If there is a relationship between the corporate image and the country's image, and that relationship is repeated between the country's image and the tourist destination image, it can be assumed that both (i.e., the corporate image and the destination image) must be related. Both are constructs related to a certain place, which could influence each other. In addition, in terms of familiarity, this relationship could be understood; the image of the companies of a country could constitute a source of information for the tourist destination.

The influence of the corporate image on the tourist destination image has recently been studied, and its influence on its cognitive dimension has been confirmed (Pérez-Tapia et al. 2019). This aspect must be studied in more depth by considering the influence of this corporate image on each factor in the tourist destination image. If the aim is to study this aspect in-depth, given that the destination image is considered a multidimensional concept, research hypotheses that make a clear distinction between the possible relationship between the corporate image and each of the constructs identified must be considered. The objective is to know how and to what extend this relationship is given so that it contributes to better management of the destination and of the companies. In view of all of the considerations above, the following hypotheses are proposed:

Hypothesis 1 (H1): The corporate image has a significant influence on the affective image.

Hypothesis 2 (H2): The corporate image has a significant influence on the natural environment.

Hypothesis 3 (H3): The corporate image has a significant influence on the atmosphere.

Hypothesis 4 (H4): The corporate image has a significant influence on the cultural environment.

Hypothesis 5 (H5): The corporate image has a significant influence on the urban environment.

Concerning the destination image, a holiday is not a physical product that can be tested before it is purchased. It is an intangible experience, and its image is essential for starting the purchase process. Tourists have great difficulty in assessing the quality of tourist services that have not yet been tested, and choosing the destination to be visited becomes a difficult process for this reason. The destination image is commonly recognized as "the sum of beliefs, ideas and impressions that a person has of a destination" (Crompton 1979, p. 18).

Numerous studies have acknowledged the importance of the destination image (Almeida-Santana and Moreno-Gil 2019; Kanwel et al. 2019; Marine-Roig 2019; Yu and Hwang 2019; Buffa 2015). The image of a particular place not only influences whether it is chosen (Bigné et al. 2001; Karl and Schmude 2017), but also the travel intention (Park et al. 2017), the level of satisfaction (O'Leary and Deegan 2005; Prayag 2009) and future 
behavior (Chen and Tsai 2007). Additionally, the destination image influences the image of the product country (Elliot et al. 2011).

The general conclusion obtained from previous studies is that a positive image leads to a better performance by the destination due to a higher probability of being chosen, increased satisfaction and loyalty that imply an intention to visit again in the future, and even increased promotion and recommendations through word of mouth (Lee et al. 2014).

Most studies in the recent literature tend to consider the image as a complex construct formed by three components: cognitive, affective, and conative (Kim et al. 2017; Leković et al. 2020). The cognitive component refers to the individual's own rational and individual knowledge (Beerli and Martin 2004). The affective component relates to individuals emotional responses toward destination attributes. The conative component is related to the intention to visit, considered analogous to behavior and evolving from cognitive and affective images (Beerli and Martin 2004; Prayag 2009).

There is an obvious causal relationship between these dimensions. The cognitive component of the tourist destination image significantly influences the affective dimension (Baloglu and McCleary 1999), which means that the affective state is the result of the cognitive process begun by the individual as the result of an external stimulus. Both will have influence on a tourist's travel intentions (Breitsohl and Garrod 2016).

As Tasci and Gartner (2007, p. 413) pointed out, "despite the overwhelming amount of research on destination image, there are still many facets of this complex construct yet to be investigated empirically: image formation and its process is one of them and is a fundamental aspect that needs more research."

Given the multidimensional nature of tourist destinations, an examination of the various dimensions or attributes that they may contain is necessary. The literature contains various contributions, although one of the pioneers was the classification by Gearing et al. (1974), who distinguished between natural factors, social indices, historical components, recreational and shopping facilities, and finally, infrastructure, restaurants, and hospitality. Another study of interest was conducted by Bigné et al. (2001), who proposed the following dimensions: social and cultural, historical, economic and political system, and finally, the human dimension.

Empirical research by numerous authors has shown that the image is a multidimensional phenomenon and that the cognitive dimension influences the affective dimension. Recently, authors like Hernández-Mogollón et al. (2018) still considered the analysis of the destination image in terms of their cognitive-affective aspects very relevant. In the case that concerns us here, it is interesting to determine how that relationship behaves if instead of making the general comparison with the image's cognitive dimension, a general comparison is made with each of the underlying subdimensions of this dimension. The information obtained will therefore be much richer and more thorough. This information goes beyond the scope of the information obtained to date and enables much more successful knowledge and management of a destination. This led us to propose the following hypotheses:

Hypothesis 6 (H6): The natural environment significantly influences the affective image.

Hypothesis 7 (H7): The atmosphere significantly influences the affective image.

Hypothesis 8 (H8): The cultural environment significantly influences the affective image.

Hypothesis 9 (H9): The urban environment significantly influences the affective image.

Figure 1 shows graphically all the aforementioned hypotheses.

\section{Methodology}

A quantitative empirical investigation was carried out to test the proposed hypotheses and the analysis model (Carlisle et al. 2021; Mercadé-Melé et al. 2021). The survey is a good 
tool to investigate attitudes and actions (Almeida-García et al. 2020; McLoughlin et al. 2020) and is widely used in the social sciences (McLoughlin et al. 2020; Carlisle et al. 2021; Molina-Gómez et al. 2021). With the questionnaire, we can obtain the data to build the structural equation model (Mercadé-Melé et al. 2019, 2021). This study used a structured questionnaire presented to university students who are citizens of South Korea as a data collection tool (Pérez-Tapia et al. 2019). The questionnaire was self-administered both via the Internet (Carlisle et al. 2021) and in person by interviewers (Molina-Gómez et al. 2021). The questionnaire was translated into Korean for better understanding. In order to evaluate the questionnaire and avoid possible errors, a pre-test was carried out, which was initially distributed to 20 Korean tourists during their holiday to Spain. South Korean researchers helped to distribute the questionnaires in South Korea. The survey was conducted between April and November 2018.

The convenience sampling method was used, because the subject being analysed required a specific population segment: Korean residents with a university education. This group of respondents was selected for several reasons: (1) Spain and South Korea are very geographically distant countries, but this group seems to have a greater knowledge of the companies operating at an international level; and (2) they are the most interesting segment for promoting Spain and Europe in South Korea and may be the business managers of the future (Mercadé-Melé et al. 2018; Carlisle et al. 2021). Although the sampling method was not probabilistic, convenience sampling is often used in social research. As Sirakaya et al. (2003) pointed out, when it is difficult to obtain a complete sampling frame, convenience sampling is suitable. This practice is also common in the tourism field due to the difficulty involved in obtaining large samples of the study population (Bigné et al. 2012; AlmeidaGarcía et al. 2020; Molina-Gómez et al. 2021).

After the data from the questionnaires had been collected and cleaned, 409 valid questionnaires were obtained. The sampling error was 4.8 percent, and the confidence level was $95 \%$. Table 1 shows the main sociodemographic characteristics of the profile of the population of South Korean university students who were surveyed in this study.

Table 1. Sociodemographic characteristics.

\begin{tabular}{ccc}
\hline Variables & & Percentage (\%) \\
\hline Gender & Man: $53.3 \%$ & Woman: $46.7 \%$ \\
\hline \multirow{2}{*}{ Age } & $18-24$ years old: $44.3 \%$ & 45-64 years: $22.5 \%$ \\
& $25-44$ years: $32.3 \%$ & More than 65 years: $1.0 \%$ \\
\hline Marital status & Single: $56.0 \%$ & Divorced: $0.7 \%$ \\
& Married:39.9\% $\%$ & Living with a partner: $1.7 \%$ \\
& Widowed: $0.2 \%$ & No opinion $/$ No reply: $1.0 \%$ \\
\hline \multirow{2}{*}{ Occupation } & Separated: $0.5 \%$ & Homemaker: $0.2 \%$ \\
& In active employment: $50.9 \%$ & Unemployed: $0.7 \%$ \\
\hline Monthly income & From $\$ 0$ to $\$ 835: 21.3 \%$ & Over $\$ 3335: 10.8 \%$ \\
& From $\$ 836$ to $\$ 1667: 9.5 \%$ & Other income levels: $2.0 \%$ \\
& From $\$ 1668$ to $\$ 2500: 23.7 \%$ & No opinion or no reply: $10.0 \%$ \\
\hline
\end{tabular}

The items used in the questionnaire were part of scales based on a comprehensive review of the literature. This review supports their reliability and validity, as they have been widely used by numerous highly reputed authors.

The corporate image was measured using a structured methodology. In this case, because the questionnaires were aimed at consumers (a key group in any competitive market), a scale that included 11 attributes consistent with this (reliable, young, creative, dynamic, innovative, socially responsible, good after-sales service, technologically advanced, concerned about the environment, high quality products, and good value for the 
money). In specific terms, the respondents used a seven-position Likert scale to give their opinion about each of the factors related to the image of Spanish companies $(1=$ complete disagreement; 7 = complete agreement).

The measurement of the destination image was based on a list of attributes of the image. In line with the most recent studies, the need to include both cognitive and affective evaluations to obtain an overall image was taken into consideration (Baloglu and McCleary 1999; Del Bosque and Martín 2008; Echtner and Ritchie 1991).

A seven-point Likert scale and a semantic differential scale with four items were used to measure the affective component of the image: boring-fun, stressful-relaxing, depressingexciting, and unpleasant-pleasant. This was carried out according to the studies that confirm the validity of the scales of Baloglú and Brinberg (1997) and Kim and Richardson (2003).

Meanwhile, scales extracted from several previous studies were used to measure the cognitive component of the image (Del Bosque and Martín 2008; Echtner and Ritchie 1991). To measure this component, 18 items were used according to the authors cited, and these were measured using a seven-point Likert scale $(1=$ complete disagreement; $7=$ complete agreement).

The factorial analysis applied to the 18 items in the destination image provided a specific measurement scale of latent variables or constructs that made up a basic subscale for understanding a destination (Table 2). The disaggregation and measurement of the cognitive image into several constructs was considered necessary to fully understand the functioning of the destination image.

Table 2. Factorial matrix of rotated cognitive components. Source: own elaboration.

\begin{tabular}{|c|c|c|c|c|c|}
\hline \multicolumn{5}{|c|}{ Components } & \\
\hline ITEMS & 1 & 2 & 3 & 4 & Constructs \\
\hline Wide variety of wildlife & 0.639 & & & & \multirow{5}{*}{$\begin{array}{c}\text { Cognitive Natural } \\
\text { environment }\end{array}$} \\
\hline Scenic beauty & 0.724 & & & & \\
\hline Beautiful parks and natural areas & 0.799 & & & & \\
\hline Pleasant climate & 0.734 & & & & \\
\hline Attractive beaches & 0.702 & & & & \\
\hline Hospital destination & & 0.669 & & & \multirow{4}{*}{ Cognitive Atmosphere } \\
\hline Opportunities for adventure & & 0.624 & & & \\
\hline Peaceful tourist destination & & 0.795 & & & \\
\hline Appropriate destination for rest & & 0.711 & & & \\
\hline Numerous cultural attractions & & & 0.612 & & \multirow{4}{*}{$\begin{array}{l}\text { Cognitive Cultural } \\
\text { environment }\end{array}$} \\
\hline Interesting cultural activities & & & 0.751 & & \\
\hline Customs worth discovering & & & 0.792 & & \\
\hline Rich and varied cuisine & & & 0.649 & & \\
\hline Accessible destination & & & & 0.831 & \multirow{5}{*}{$\begin{array}{c}\text { Cognitive Urban } \\
\text { environment }\end{array}$} \\
\hline Shopping facilities & & & & 0.798 & \\
\hline Quality accommodation & & & & 0.774 & \\
\hline Good value & & & & 0.713 & \\
\hline Safe tourist destination & & & & 0.663 & \\
\hline$\%$ variance explained & $52.88 \%$ & $10.73 \%$ & $5.38 \%$ & $4.94 \%$ & \\
\hline Kaiser-Meyer-Olkin index & 0.928 & & & & \\
\hline Bartlett's test of sphericity & Chi-s & $=5697.16$ & .000 & & \\
\hline
\end{tabular}

Note: Extraction method: Principal component analysis; Varimax rotation method with Kaiser-Meyer-Olkin (KMO). 


\section{Results}

As noted above, this research examined the underlying factors of the cognitive image in order to determine its heterogeneity. An exploratory factorial analysis was performed to that end, which enabled four dimensions of the cognitive image to be extracted (Table 2). The first of the factors obtained explained $52.88 \%$ of the total variance of the matrix of the cognitive image. This dimension had five items and was classified as the cognitive natural dimension. The second factor extracted had four items, explained $10.73 \%$ of the total variance, and was called the cognitive atmosphere dimension. The third factor extracted explained $5.38 \%$ of the total variance, was called the cognitive cultural dimension, and had four items. Finally, the fourth factor extracted explained $4.94 \%$ of the total variance, had five items, and was called the cognitive infrastructure dimension. These four factors extracted therefore explained $73.93 \%$ of the total variance (with Kaiser-Meyer-Olkin $=0.928$ ). The theoretical model was subsequently validated (Figure 1) based on confirmatory factorial analysis (CFA), which demonstrated the validity of the factor structure previously obtained with exploratory factorial analysis (EFA) (Hair et al. 2010).

The first factor had several attributes related to nature and climate and included the diversity of wildlife, scenic beauty, parks and natural areas, a pleasant climate, and attractive beaches. These all refer to the natural environment.

The second factor was classified as atmosphere because it included attributes related to the sensations caused by the destination, and in particular, a destination that was hospitable, quiet, and suitable for rest and provided opportunities for adventure.

The third factor consisted of various elements linked to the cultural activities in the destination. It included the following attributes: numerous cultural attractions, interesting cultural activities, customs worth discovering, and rich and varied cuisine. This latter factor was called the cultural environment.

Finally, the fourth factor had several attributes associated with infrastructure, and it specifically included accessibility, shopping facilities, quality accommodation, good value for the money, and a safe destination. This was called the urban environment.

These factors that were obtained made up the new scale referred to above. The cognitive construct therefore consisted of a broader dimension, giving the place several factors, subdimensions, or new constructs. In the literature, each author included different attributes depending on the destination to be assessed. These four factors, which we call the core elements, combine the multiple attributes that make up the essential elements that a destination must have: urban environment, natural environment, cultural environment, and atmosphere. If these four elements have a positive mean score, the destination can be considered competitive. If any of these elements does not have the desired score, the institutions or managers of the destination should take steps to improve it.

\subsection{Analysis of the Psychometric Properties of the Measurement Model}

To assess the measurement validity, reliability, and goodness, a confirmatory factor analysis which contained all the constructs of our theory model was estimated using STATA 15. Both the corporate and affective images were measured using validated scales in this study. We aimed to examine the heterogeneity of the cognitive dimension using exploratory factorial analysis (EFA). Confirmatory factorial analysis (CFA) was then performed to validate the factor structure previously obtained with the EFA and to thereby validate the factor structure we obtained.

Table 3 shows that all the variables in the theoretical model fulfilled all the measures of reliability. The Cronbach's alpha $(\alpha)$ was higher than 0.7 (Cronbach 1951), the composite reliability index (CRI) was higher than 0.7 , and the average variance extracted (AVE) was higher than 0.5 (Fornell and Larcker 1981). The measures of validity were adequate in all cases when the coefficients of standardized loadings had values higher than 0.5 and their means were higher than 0.7 (Hair et al. 2010). The convergent validity was thereby fulfilled. Table 4 also confirms the discriminant validity of the measurement model, as it did not present any confidence interval of correlations with a value of one (Anderson 
and Gerbing 1988). As for the measures of goodness, the root mean square error of approximation (RMSEA), was less than 0.08 (Steiger 1990), the Tucker-Lewis index (TLI), and the comparative fit index (CFI) were close to one (Hu and Bentler 1999), and the standardized root mean square residual (SRMR) was lower than 0.1 (Williams et al. 2009). The only indicator that was not fulfilled was the $\chi^{2}$, but this was sensitive to the sample size (Bentler and Bonett 1980).

Table 3. Confirmatory factorial analysis with psychometric properties.

\begin{tabular}{|c|c|c|c|c|c|c|}
\hline Constructs Dimension & Items & Loads & $\begin{array}{c}\text { Average } \\
\text { Loads }\end{array}$ & $\alpha$ & AVE & CRI \\
\hline \multirow{11}{*}{ Corporate Image } & CI_1 & 0.7679 & \multirow{11}{*}{0.779} & \multirow{11}{*}{0.9405} & \multirow{11}{*}{0.610} & \multirow{11}{*}{0.945} \\
\hline & CI_2 & 0.7166 & & & & \\
\hline & CI_3 & 0.8186 & & & & \\
\hline & CI_4 & 0.6533 & & & & \\
\hline & CI_5 & 0.8122 & & & & \\
\hline & CI_6 & 0.8108 & & & & \\
\hline & CI_7 & 0.8116 & & & & \\
\hline & CI_8 & 0.8208 & & & & \\
\hline & CI_9 & 0.7775 & & & & \\
\hline & CI_10 & 0.8151 & & & & \\
\hline & CI_11 & 0.7677 & & & & \\
\hline \multirow{5}{*}{ Natural Environment } & NAT_1 & 0.5281 & \multirow{5}{*}{0.780} & \multirow{5}{*}{0.8889} & \multirow{5}{*}{0.624} & \multirow{5}{*}{0.890} \\
\hline & NAT_2 & 0.8428 & & & & \\
\hline & NAT_3 & 0.8855 & & & & \\
\hline & NAT_4 & 0.8324 & & & & \\
\hline & NAT_5 & 0.8094 & & & & \\
\hline \multirow{4}{*}{ Atmosphere } & ATM_1 & 0.7373 & \multirow{4}{*}{0.791} & \multirow{4}{*}{0.8762} & \multirow{4}{*}{0.629} & \multirow{4}{*}{0.871} \\
\hline & ATM_2 & 0.726 & & & & \\
\hline & ATM_3 & 0.8534 & & & & \\
\hline & ATM_4 & 0.8475 & & & & \\
\hline \multirow{4}{*}{ Cultural Environment } & CUL_1 & 0.7843 & \multirow{4}{*}{0.797} & \multirow{4}{*}{0.8837} & \multirow{4}{*}{0.635} & \multirow{4}{*}{0.874} \\
\hline & CUL_2 & 0.7818 & & & & \\
\hline & CUL_3 & 0.8474 & & & & \\
\hline & CUL_4 & 0.7729 & & & & \\
\hline \multirow{5}{*}{ Urban Environment } & URB_1 & 0.7547 & \multirow{5}{*}{0.802} & \multirow{5}{*}{0.8994} & \multirow{5}{*}{0.650} & \multirow{5}{*}{0.902} \\
\hline & URB_2 & 0.8416 & & & & \\
\hline & URB_3 & 0.905 & & & & \\
\hline & URB_4 & 0.8352 & & & & \\
\hline & URB_5 & 0.6732 & & & & \\
\hline \multirow{4}{*}{ Affective Image } & AFF_1 & 0.8441 & \multirow{4}{*}{0.847} & & & \\
\hline & AFF_2 & 0.7877 & & & & \\
\hline & AFF_3 & 0.8677 & & 0.918 & 0.719 & 0.911 \\
\hline & AFF_4 & 0.8894 & & & & \\
\hline Higher IC CoI & ations $(\mathrm{C}$ & Iral Envi & nent - Aff & ive): $(0.8$ & $-0.901)$ & \\
\hline & & Soodness & & & & \\
\hline$S-B \times 2=1526.69$ & & & & & RMSEA & SRMR \\
\hline$(p=0.000)$ & & & & & 0.073 & 0.054 \\
\hline
\end{tabular}


Table 4. Test of discriminant validity. Source: own elaboration.

\begin{tabular}{|c|c|c|c|c|c|c|}
\hline $\begin{array}{l}\text { Constructs or } \\
\text { Dimensions }\end{array}$ & CI & NE & AT & $\mathrm{CE}$ & UE & AI \\
\hline Corporate Image (CI) & 0.610 & & & & & \\
\hline Natural Environment (NE) & $0.394-0.612$ & 0.624 & & & & \\
\hline Atmosphere (AT) & $0.407-0.604$ & $0.649-0.845$ & 0.629 & & & \\
\hline Cultural Environment (CE) & $0.389-0.598$ & $0.776-0.871$ & $0.660-0.857$ & 0.635 & & \\
\hline Urban Environment (UE) & $0.378-0.567$ & $0.433-0.646$ & $0.684-0.818$ & $0.566-0.763$ & 0.650 & \\
\hline Affective Image (AI) & $0.429-0.610$ & $0.709-0.845$ & $0.655-0.859$ & $0.830-0.901$ & $0.571-0.760$ & 0.719 \\
\hline
\end{tabular}

Note: The main diagonal represents the Average Variance Extracted (AVE). Confidence intervals for correlations are reported below.

\subsection{Analysis of the Structural Relationships and Hypotheses Considered}

Table 5 shows the standardized coefficients of the structural relationships studied in the theoretical model.

Table 5. Evaluation of structural models. Source: own elaboration.

\begin{tabular}{ccccc}
\hline Hypothesis & Structural Relationship & Coef. & $\boldsymbol{t}$ Value & Contrast \\
\hline $\mathrm{H}_{1}$ & $\mathrm{CI} \rightarrow$ Affective & 0.0259 & 0.310 & Not Supported \\
$\mathrm{H}_{2}$ & $\mathrm{CI} \rightarrow$ Natural environment & 0.5506 & $12.04^{* * *}$ & Supported \\
$\mathrm{H}_{3}$ & $\mathrm{CI} \rightarrow$ Atmosphere & 0.5523 & $13.18^{* * *}$ & Supported \\
$\mathrm{H}_{4}$ & $\mathrm{CI} \rightarrow$ Cultural environment & 0.5451 & $12.01^{* * *}$ & Supported \\
$\mathrm{H}_{5}$ & $\mathrm{CI} \rightarrow$ Urban environment & 0.5164 & $11.99^{* * *}$ & Supported \\
$\mathrm{H}_{6}$ & Natural environment $\rightarrow$ Affective & 0.2601 & $5.29^{* * *}$ & Supported \\
$\mathrm{H}_{7}$ & Atmosphere $\rightarrow$ Affective & 0.1772 & $3.35^{* * *}$ & Supported \\
$\mathrm{H}_{8}$ & Cultural environment $\rightarrow$ Affective & 0.5449 & $14.41^{* * *}$ & Supported \\
$\mathrm{H}_{9}$ & Urban environment $\rightarrow$ Affective & 0.1636 & $3.76^{* * *}$ & Supported \\
\hline Note: ${ }^{* * *} p$-value $<0.01$. & & &
\end{tabular}

Table 5 shows that there was no direct relationship between the destination's corporate image and its affective image (H1 was not supported). However, there was a relationship between the corporate image and the affective image through the mediating variables that made up the different factors in the cognitive image (i.e., the natural environment, the atmosphere, the cultural environment, and the urban environment) (H2-H9 were supported). The relationship between the corporate and the affective image therefore only occurred indirectly through the cognitive dimension, and there was no empirical evidence for a direct causal relationship. The greatest direct causal relationship was between the corporate image and the cognitive atmosphere dimension $(\beta=0.5523)$ and between the corporate image and the natural environment cognitive dimension ( $\beta=0.5506)$. Furthermore, the complexity of the cognitive dimension means that this concept must be broken down into different factors. If we examine the total indirect effect of the corporate image on the affective dimension based on the various constituent factors of the cognitive dimension, the greatest effect was caused by the cultural factor (0.297) (Table 6).

Table 6. Indirect effects of the corporate image (CI) on the affective image.

$\begin{array}{cc}\mathrm{CI} \rightarrow \text { Natural environment } \rightarrow \text { Affective } & 0.143 \\ \mathrm{CI} \rightarrow \text { Atmosphere } \rightarrow \text { Affective } & 0.098 \\ \mathrm{CI} \rightarrow \text { Cultural environment } \rightarrow \text { Affective } & 0.297 \\ \mathrm{CI} \rightarrow \text { Urban environment } \rightarrow \text { Affective } & 0.084\end{array}$

Figure 2 shows the model with its respective structural coefficients. 


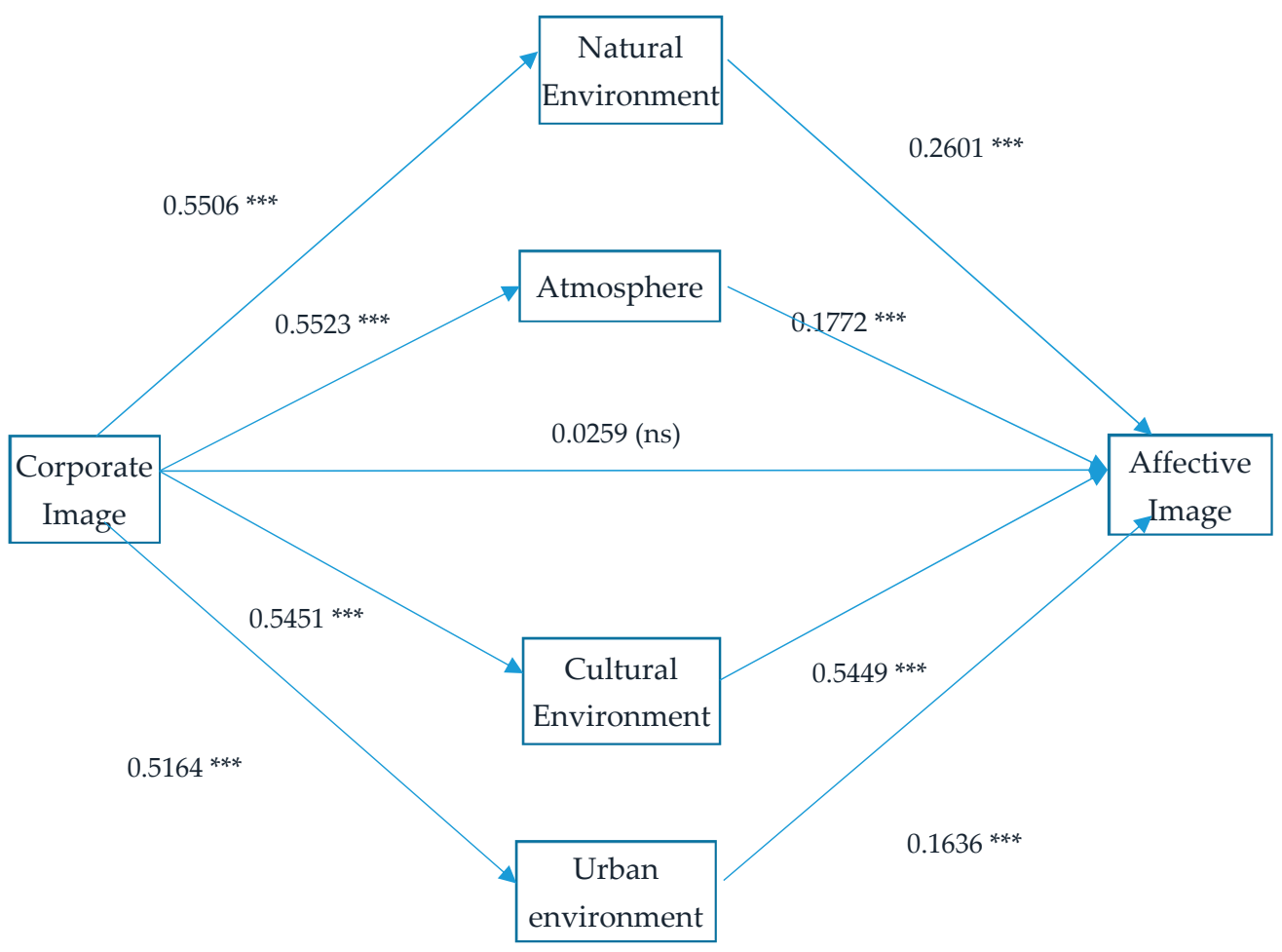

Figure 2. Structural model. Note that $(\mathrm{ns})=$ not significant. ${ }^{* * *} p$-value $<0.01$.

\section{Discussion}

Numerous scholars have examined the factors that influence the creation of a destination image (Acosta Pereira et al. 2019; Xiao et al. 2020; Cheng et al. 2020; De las Heras-Pedrosa et al. 2020; Li et al. 2020; Iglesias-Sánchez et al. 2020; Ruan et al. 2017). However, it is difficult to find authors who have examined the corporate image as a factor influencing the destination image. While it is true that some authors related these two concepts, they basically linked the management of a corporate image to the management of a destination or its image. These researchers argued that an organization's situation is similar to the context of tourism, as the image that tourists have of a destination is a very important factor (Echtner and Ritchie 1991; Tasci and Gartner 2007), which ultimately influences their final choice (Chen and Tsai 2007).

However, the literature contained no research regarding the influence of the corporate image on the destination image, except for the study by Pérez-Tapia et al. (2019). The results of this study to a large extent confirm the findings of this previously mentioned study: the corporate image has no direct influence on the affective dimension (H1). On the contrary, there is an indirect relationship through the cognitive dimension of the destination image (Table 6, Figure 2).

The first question studied suggests that the structure of the image and its cognitive dimension is determined. This has led to the identification of four latent constructs or variables: (1) the natural environment, or the destination's attributes related to its landscape, natural areas, and climate; (2) the atmosphere, which refers to the peace and rest that the destination offers and also includes a more dynamic aspect such as adventure; (3) the cultural environment, or the attributes that are usually associated with a cultural destination and which make it more appealing to tourists seeking cultural attractions and gastronomy; and (4) the urban environment, which refers to the services and attributes that make up the basic facilities available in a tourist destination, such as transport, safety, accommodation, and shopping centres.

After identifying these variables, a model to examine the relationship between the corporate image of Spanish companies abroad and their possible influence on the destination image was sought. Tourism institutions need to be aware of every factor that 
influences the destination image. There are clearly some personal factors, which are very difficult to influence even when they can be identified (e.g., personality and motivations). However, there are some stimulus factors that can be controlled to a greater or lesser extent (e.g., sources of information and attributes of the destination). The corporate image of companies could be included here as an item that voluntarily or involuntarily conveys an image abroad, and this may be the cause of knowledge of the destination or a better or poorer image of it.

The influence of the corporate image on the cognitive and affective dimension was considered in the proposed model, because determining the extent to which it influences each dimension is considered very important. This study also argues that it is essential to examine the relationship with the affective dimension, since it is closely related to motivations, which are what lead people to travel (Beerli and Martin 2004).

The corporate image has no direct influence on the affective image. This relationship is not significant, and as such, it appears that knowledge of companies does not lead to an improved emotional perception of the destination. However, a greater direct causal relationship between the corporate image and the natural, atmospheric, and cultural dimensions of the cognitive image is confirmed (Hypotheses 2-5). In this case, the image of companies abroad could act as an additional attribute or characteristic of the destination, raising the destination's profile and therefore reinforcing the cognitive dimension of the destination image in other countries. This relationship is perhaps not as strong in the urban environment variable because it includes attributes that are less well known to tourists, and as such, it has a lower mean score than the other dimensions. This is corroborated by the results obtained by Bigné et al. (2012), who examined the relationship between some image factors and satisfaction and post-purchase behaviour intentions and confirmed that perceptions related to infrastructure played a less influential role. This may be because the destination's infrastructure and facilities are not distinguishing characteristics of destinations because they are taken for granted.

The results of Hypotheses 6-9, which analysed the relationship of the influence between the factors identified in the cognitive image and the affective image, showed that all the relationships were significant. In other words, the results suggest that all the dimensions identified - natural environment, atmosphere, cultural environment, and urban environment-have a significant influence on the affective image. In this respect, it should be noted that this relationship is more intense for the cultural environment dimension. Likewise, if the total indirect effect between the corporate and the affective image is analysed (Figure 2, Table 6), the results suggest that the greatest effect takes place through the cultural dimension. This relationship may be due to the fact that the image of Spanish companies in other countries is very closely identified with the Spanish character and culture and that they emphasize their Spanish identity, meaning that tourists could identify them as a part of Spanish cultural heritage. This relationship with the affective dimension of the image also suggests that some emotions could be explained by the nature of Spanish companies.

These results confirm the need to cultivate the image of companies abroad so that they convey an image of trust and social and ethical responsibility that transcends national borders and disseminates the country image.

\section{Conclusions}

The image is generally assumed to consist of two dimensions: cognitive and affective (Hosany et al. 2006). The combined analysis of these two dimensions gives an overall image that refers to a positive or negative score for the destination.

According to Ahmed (1996), most tourist destinations' marketing strategies focus on the overall image instead of distinguishing between its various constituent dimensions. This is a simplification of something that is much more profound. Images are complex, heterogeneous, and sometimes unconscious, and the way they are measured, which is generally based on the evaluation of attributes, does not enable them to be studied in depth. 
Some characteristics may be highly rated, while others are not. Ahmed (1996) argued that individuals can present an assessment of the components of the image which is very different from their overall perception of the destination they visit.

The cognitive dimension contains various components which are not necessarily related to each other, despite being related to the rational knowledge of a destination. The problem arises when the cognitive dimension is studied as a whole and not as a sum of factors, as in this study. Coshall (2000) noted that the structured technique does not permit individuals to express their own perception of the destination (i.e., it does not include the components of the image that reflect the individuals' different perceptions).

This study was based on the need to learn more about the destination image at both the academic level and in terms of the management of the destination itself. From the complex to the simple and from the simple to the complex could summarize the objective proposed and achieved in this research.

Based on the first statement, (i.e., from the complex to the simple), a new scale has been created that has provided four core or basic elements which any tourist destination must have. There has been no consensus to date regarding the characteristics that a destination requires, and as such, a wide diversity of items has been proposed without any specific criteria. This scale, which we could call the four core elements, simplifies measurement of the destination. Each factor (urban environment, natural environment, cultural environment, and atmosphere) may include different characteristics selected by the researcher, but these four elements must undoubtedly be included.

The second statement, (i.e., from the simple to the complex) refers to the way in which the relationships between the corporate image, the cognitive dimension of the image and its affective dimension have been examined. Carrying out a detailed analysis of the cognitive image as a moderating variable is a further step forward. To do this, four core or basic factors in the cognitive dimension were obtained, and their relationships were analysed individually, providing much more enriching information.

This research has a clear practical involvement, as it allows the destination to know its weaknesses and strengths according to the image of its potential tourists. The destination will be able to know much more specifically which aspect to improve and not lose perspective, since this new way of measuring the image allows one to work on the essentials without wasting resources on aspects that are perceived in a positive way. It should be noted at this point that we are trying to measure the preconceived image of the destination. This image is basic to encourage a tourist's potential to visit the destination or discard it.

The main limitation of this study is the chosen sample, as it focuses on the image of a group of potential tourists from an awfully specific country (South Korea). This sample should be more heterogeneous, including perceptions of citizens of other countries.

Future lines of research could include replicating this study in other countries with different types of companies and cultural spheres to determine whether the influence identified is maintained and expanding the analysis of the corporate image as an intermediate dimension in the destination image.

Author Contributions: Conceptualization, G.P.-T., F.A.-G. and P.M.-M..; methodology, P.M.-M..; software, P.M.-M..; validation, G.P.-T., F.A.-G. and P.M.-M..; formal analysis, P.M.-M.; investigation, G.P.-T.; resources, G.P.-T.; data curation, P.M.-M..; writing—original draft preparation, G.P.-T. and F.A.G.; writing-review and editing, G.P.-T. and F.A.-G.; visualization, G.P.-T. and F.A.-G.; supervision, F.A.-G.; project administration, G.P.-T.; funding acquisition, University of Málaga. All authors have read and agreed to the published version of the manuscript.

Funding: University of Málaga.

Data Availability Statement: All data is in the article.

Conflicts of Interest: The authors declare no conflict of interest. 


\section{References}

Acosta Pereira, Lucimari, Flôres Limberger Pablo, Luis Carlos Da Silva Flores, and Melise De Lima Pereira. 2019. An Empirical Investigation of Destination Branding: The Case of the City of Rio de Janeiro, Brazil. Sustainability 11: 90. [CrossRef]

Ahmed, Zafar U. 1996. The need for the identification of the constituents of a destination's tourist image: A promotion segmentation perspective. Journal of Professional Services Marketing 14: 37-60. [CrossRef]

Almeida-García, Fernando, Janire Domínguez-Azcue, Pere Mercadé-Melé, and Gema Pérez-Tapia. 2020. Can a destination really change its image? The roles of information sources, motivations, and visits. Tourism Management Perspectives 34: 100662. [CrossRef]

Almeida-Santana, Arminda, and Sergio Moreno-Gil. 2019. Perceived Sustainable Destination Image: Implications for Marketing Strategies in Europe. Sustainability 11: 6466. [CrossRef]

Anderson, James C., and David W. Gerbing. 1988. Structural equation modeling in practice: A review and recommended two-step approach. Psychological Bulletin 103: 411. [CrossRef]

Balmer, John M., and Edmund R. Gray. 2003. Corporate brands: What are they? What of them? European Journal of Marketing 37: 972-97. [CrossRef]

Baloglú, Seyhmus, and David Brinberg. 1997. Affective images of tourism destinations. Journal of Travel Research 35: 11-15. [CrossRef]

Baloglu, Seyhmus, and Ken W. McCleary. 1999. A model of destination image formation. Annals of Tourism Research 26: 868-97. [CrossRef]

Beerli, Asunción, and Josefa D. Martin. 2004. Factors influencing destination image. Annals of Tourism Research 31: 657-81. [CrossRef]

Bentler, Peter M., and Douglas G. Bonett. 1980. Significance tests and goodness of fit in the analysis of covariance structures. Psychological Bulletin 88: 588. [CrossRef]

Bernstein, David. 1984. Company Image and Reality: A Critique of Corporate Communications. New York: Taylor \& Francis.

Bigné, J. Enrique, M. Isabel Sanchez, and Javier Sanchez. 2001. Tourism image, evaluation variables and after purchase behaviour: Inter-relationship. Tourism Management 22: 607-16. [CrossRef]

Bigné, Enrique, Isabel S. García, and Rafael C. Pérez. 2012. El papel de la imagen del destino en la valoración y comportamiento postcompra del turista de sol y playa. Papers de Turisme 42. Available online: http: / / www.papersdeturisme.gva.es/ojs/index. $\mathrm{php} /$ Papers/article/view/57 (accessed on 31 March 2021).

Breitsohl, Jan, and Brian Garrod. 2016. Assessing tourists' cognitive, emotional and behavioural reactions to an unethical destination incident. Tourism Management 54: 209-20. [CrossRef]

Brooks, Margaret E., Scott Highhouse, and Gary Gregarus. 2009. An Organizational Impression Management Perspective on the Formation of Corporate Reputations. Journal of Management 35: 1481-93.

Buffa, Federica. 2015. Young Tourists and Sustainability. Profiles, Attitudes, and Implications for Destination Strategies. Sustainability 7: 14042-62. [CrossRef]

Capriotti, Paul. 2009. Branding Corporativo. Santiago de Chile: Colección libros de la empresa.

Carlisle, Sheena, Karam Zaki, Mohamed Ahmed, Louise Dixey, and Emmet McLoughlin. 2021. The Imperative to Address Sustainability Skills Gaps in Tourism in Wales. Sustainability 13: 1161. [CrossRef]

Chen, Ching Fu, and DungChun Tsai. 2007. How destination image and evaluative factors affect behavioral intentions? Tourism Management 28: 1115-22. [CrossRef]

Cheng, Weiling, Hsientang Tsai, Hsiuhui Chuang, Paohui Lin, and Tzuya Ho. 2020. How Can Emerging Event Sustainably Develop in the Tourism Industry? From the Perspective of the SOR Model on a Two-Year Empirical Study. Sustainability 12: 10075. [CrossRef]

Cohen, Scott A., Girish Prayag, and Miguel Moital. 2014. Consumer behaviour in tourism: Concepts, influences and opportunities. Current Issues in Tourism 17: 872-909. [CrossRef]

Coshall, John T. 2000. Measurement of tourists' images: The repertory grid approach. Journal of Travel Research 39: 85-89. [CrossRef]

Crompton, John L. 1979. An assessment of the image of Mexico as a vacation destination and the influence of geographical location upon that image. Journal of Travel Research 17: 18-23. [CrossRef]

Crompton, John L., Paul C. Fakeye, and Chi-Chuan Lue. 1992. Positioning: The example of the Lower Rio Grande Valley in the winter long stay destination market. Journal of Travel Research 31: 20-26. [CrossRef]

Cronbach, Lee J. 1951. Coefficient alpha and the internal structure of tests. Psychometrika 16: 297-334. [CrossRef]

De las Heras-Pedrosa, Carlos, Elena Millan-Celis, Patricia P. Iglesias-Sánchez, and Carmina Jambrino-Maldonado. 2020. Importance of Social Media in the Image Formation of Tourist Destinations from the Stakeholders' Perspective. Sustainability 12: 4092. [CrossRef]

Del Bosque, Ignacio R., and Héctor San Martín. 2008. Tourist satisfaction a cognitive-affective model. Annals of Tourism Research 35: 551-73. [CrossRef]

Dowling, Grahame R. 1993. Developing your company image into a corporate asset. Long Range Planning 26: 101-09. [CrossRef]

Dwyer, Larry, and Chulwon Kim. 2003. Destination competitiveness: Determinants and indicators. Current Issues in Tourism 6: 369-414. [CrossRef]

Echtner, Charlotte M., and J. Brent Ritchie. 1991. The meaning and measurement of destination image. Journal of Tourism Studies 2: 2-12.

Elliot, Statia, Nicolas Papadopoulos, and Samuel Seongseop Kim. 2011. An integrative model of place image: Exploring relationships between destination, product, and country images. Journal of Travel Research 50: 520-34. [CrossRef]

Fombrun, Charles. 2015. Reputation. Wiley Encyclopedia of Management, 1-3.

Fornell, Claes, and David F. Larcker. 1981. Structural equation models with unobservable variables and measurement error: Algebra and statistics. Journal of Marketing Research 18: 382-88. [CrossRef] 
Gartner, William C. 1994. Image formation process. Journal of Travel E Tourism Marketing 2: 191-216.

Gearing, Charles E., William W. Swart, and Turgut Var. 1974. Establishing a measure of touristic attractiveness. Journal of Travel Research 12: 1-8. [CrossRef]

Gupta, Vibhuti, Kwanghee Jung, and Seung-Chul Yoo. 2020. Exploring the Power of Multimodal Features for Predicting the Popularity of Social Media Image in a Tourist Destination. Multimodal Technologies and Interaction 4: 64. [CrossRef]

Hair, Joseph F., William C. Black, Barry J. Babin, and Rolph E. Anderson. 2010. Multivariate Data Analysis. Upper Saddle River New Jersey: Pearson Prentice Hall.

Hernández-Mogollón, Jose Manuel, Paulo Alexandre Duarte, and José Antonio Folgado-Fernández. 2018. The contribution of cultural events to the formation of the cognitive and affective images of a tourist destination. Journal of Destination Marketing $\mathcal{E}$ Management 8: $170-78$.

Highhouse, Scott, Erin E. Thornbury, and Ian S. Little. 2007. Social-identity functions of attraction to organizations. Organizational Behavior and Human Decision Processes 103: 134-46. [CrossRef]

Hosany, Sameer, Yuksel Ekinci, and Muzaffer Uysal. 2006. Destination image and destination personality: An application of branding theories to tourism places. Journal of Business Research 59: 638-42. [CrossRef]

$\mathrm{Hu}, \mathrm{Li}$-Tze, and Peter M. Bentler. 1999. Cutoff criteria for fit indexes in covariance structure analysis: Conventional criteria versus new alternatives. Structural Equation Modeling: A Multidisciplinary Journal 6: 1-55. [CrossRef]

Iglesias-Sánchez, Patricia P., Marisol B. Correia, Carmina Jambrino-Maldonado, and Carlos de las Heras-Pedrosa. 2020. Instagram as a co-creation space for tourist destination image-building: Algarve and Costa del Sol case studies. Sustainability 12: 2793. [CrossRef]

Kanwel, Shahida, Zhou Lingqiang, Muhammad Asif, Jinsoo Hwang, Abid Hussain, and Arif Jameel. 2019. The influence of destination image on tourist loyalty and intention to visit: Testing a multiple mediation approach. Sustainability 11: 6401. [CrossRef]

Karl, Marion, and Jürgen Schmude. 2017. Understanding the role of risk (perception) in destination choice: A literature review and synthesis. Tourism 65: 138-55.

Kim, Hyounggon, and Sarah L. Richardson. 2003. Motion picture impacts on destination images. Annals of Tourism Research 30: $216-37$. [CrossRef]

Kim, Sung-Eun, Kyung Young Lee, Soo Il Shin, and Sung-Byung Yang. 2017. Effects of tourism information quality in social media on destination image formation: The case of Sina Weibo. Information \& Management 54: 687-702.

Lee, Bong-Koo, Choong-Ki Lee, and Jaeseok Lee. 2014. Dynamic nature of destination image and influence of tourist overall satisfaction on image modification. Journal of Travel Research 53: 239-51. [CrossRef]

Leković, Ksenija, Slavica Tomić, Drazen Marić, and Nicola Ćurčić. 2020. Cognitive Component of the Image of a Rural Tourism Destination as a Sustainable Development Potential. Sustainability 12: 9413. [CrossRef]

Li, Yi, Xiuxiu Xu, Bo Song, and Hong He. 2020. Impact of Short Food Videos on the Tourist Destination Image-Take Chengdu as an Example. Sustainability 12: 6739. [CrossRef]

López, Carmen, Manto Gotsi, and Constantine Andriopoulos. 2011. Conceptualising the influence of corporate image on country image. European Journal of Marketing 45: 1601-41. [CrossRef]

Marine-Roig, Estela. 2019. Destination image analytics through traveller-generated content. Sustainability 11: 3392. [CrossRef]

Markwick, Nigel, and Chris Fill. 1997. Towards a framework for managing corporate identity. European Journal of Marketing 31: 396-409. [CrossRef]

McLoughlin, Emmet, James Hanrahan, and Ann Marie Duddy. 2020. Application of the European Tourism Indicator System (ETIS) for Sustainable Destination Management. Lessons from County Clare, Ireland. International Journal of Culture, Tourism and Hospitality Research 14: 273-94. [CrossRef]

Mercadé-Melé, Pere, Sebastián Molinillo, Antonio Fernández, and Lucía Porcu. 2018. CSR activities and consumer loyalty: The effect of the type of publicizing medium. Journal of Business Economics and Management 19: 431-55. [CrossRef]

Mercadé-Melé, Pere, Molina-Gómez Jesús, and Garay Lluis. 2019. To green or not to green: The influence of green marketing on consumer behaviour in the hotel industry. Sustainability 11: 4623.

Mercadé-Melé, Pere, Fandos-Herrera Carmina, and Velasco-Gómez Sofía. 2021. How corporate social responsibility influences consumer behavior: An empirical analysis in the Spanish agrifood sector. Agribusiness, 1-22. [CrossRef]

Milman, Ady, and Abraham Pizam. 1995. The role of awareness and familiarity with a destination: The central Florida case. Journal of Travel Research 33: 21-27. [CrossRef]

Molina-Gómez, Jesús, Pere Mercadé-Melé, Fernando Almeida-García, and Raquel Ruiz-Berrón. 2021. New perspectives on satisfaction and loyalty in festival tourism: The function of tangible and intangible attributes. PLoS ONE 16: e0246562. [CrossRef] [PubMed]

O'Leary, Sinéad, and Jim Deegan. 2005. Ireland's image as a tourism destination in France: Attribute importance and performance. Journal of Travel Research 43: 247-56. [CrossRef]

Papadopoulos, Nicolas, and Louise A. Heslop. 2003. Country equity and product-country images: State-of-the-art in research and implications. In Handbook of Research in International Marketing. Edited by S. C. Jain. Cheltenham: Edward Elgar, pp. 402-33.

Papadopoulos, Nicolas, Louise A. Heslop, and Gary Bamossy. 1990. A comparative image analysis of domestic versus imported products. International Journal of Research in Marketing 7: 283-94. [CrossRef] 
Park, Sung Hee, Chi-Ming Hsieh, and Choong-Ki Lee. 2017. Examining Chinese college students' intention to travel to Japan using the extended theory of planned behavior: Testing destination image and the mediating role of travel constraints. Journal of Travel $\mathcal{E}$ Tourism Marketing 34: 113-31.

Park, Deukhee, Gyehee Lee, Woo Gon Kim, and Taegoo Terry Kim. 2019. Social network analysis as a valuable tool for understanding tourists' multi-attraction travel behavioral intention to revisit and recommend. Sustainability 11: 2497. [CrossRef]

Pérez-Tapia, Gema, Pere Mercadé-Melé, and Fernando Almeida-García. 2019. Corporate image and destination image: The moderating effect of the motivations on the destination image of Spain in South Korea. Asia Pacific Journal of Tourism Research 24: 70-82. [CrossRef]

Prayag, Girish. 2009. Tourists'evaluations of destination image, satisfaction, and future behavioral intentions-The case of mauritius. Journal of Travel E Tourism Marketing 26: 836-53.

Rindova, Violina P. 1997. Part VII: Managing reputation: Pursuing everyday excellence: The image cascade and the formation of corporate reputations. Corporate Reputation Review 1: 188-94. [CrossRef]

Rodríguez, Roberto, Luis. Manuel Peteiro, and María T. Rodríguez. 2007. Reflexiones sobre cultura organizacional e instituciones en el mundo actual [versión electrónica]. Psicología Científica 1. Available online: https://psicopediahoy.com/cultura-organizacionalactual/ (accessed on 15 May 2007).

Ruan, Wen-Qi, Yong-Quan Li, and Chih-Hsing Sam Liu. 2017. Measuring Tourism Risk Impacts on Destination Image. Sustainability 9: 1501. [CrossRef]

Schroeder, Tim. 1996. The relationship of residents' image of their state as a tourist destination and their support for tourism. Journal of Travel Research 34: 71-73. [CrossRef]

Sirakaya, Ercan, Muzaffer Uysal, and Carlton F. Yoshioka. 2003. Segmenting the Japanese tour market to Turkey. Journal of Travel Research 41: 293-304. [CrossRef]

Steiger, James H. 1990. Structural model evaluation and modification: An interval estimation approach. Multivariate Behavioral Research 25: 173-80. [CrossRef]

Tasci, Asli D. A., and William C. Gartner. 2007. Destination image and its functional relationships. Journal of Ttravel Research 45: 413-25. [CrossRef]

Williams, Larry J., Robert J. Vandenberg, and J. R. Edwards. 2009. 12 structural equation modeling in management research: A guide for improved analysis. Academy of Management Annals 3: 543-604. [CrossRef]

Xiao, Xin, Chaoyang Fang, and Hui Lin. 2020. Characterizing Tourism Destination Image Using Photos' Visual Content. ISPRS International Journal of Geo-Information 9: 730. [CrossRef]

Yu, Cheon, and Yun Seop Hwang. 2019. Do the Social Responsibility Efforts of the Destination Affect the Loyalty of Tourists? Sustainability 11: 1998. [CrossRef] 